\title{
THE POSITION OF THE JUDICIARY IN THE UNITED STATES
}

\author{
By Alpheus Henry Snow, \\ Attorney-at-Law, Washington, D.C.
}

At the present time two circumstances are directing public attention to the position which the judiciary holds in the American political system. The initiative, the referendum and the recall are extending widely, and the prospect is that they will soon become prevalent throughout our states. It is clear that if these methods of controlling governmental action by popular vote should be carried sufficiently far, they might be used so as to extinguish the power which our courts have to treat as void any governmental action which is in excess of the powers granted by our written constitutions. At the same time that the position of our judiciary is thus endangered by the coming of these new forms of political action, its position has been seriously weakened, in the eyes of many of our best citizens, by its own action in exercising its power to hold laws unconstitutional. It is probably true that some of our courts have exercised this power in a retrogressive manner; that is, in such a way as to interfere with the people in their proper development and progress, and with the nation in its fair competition with foreign nations. Thus the position of our judiciary in our political system is at the same time endangered from without and from within. If it be true that our courts are proving themselves unable properly to perform the high and extraordinary functions which we have laid upon them, those who advocate the extension of the initiative, the referendum and the recall are entitled to be heard with attention. If our system is sound, and is merely operating badly for the moment on account of some specific defect or ambiguity in our constitutions, or because we are passing through some temporary social or economic phase or condition, or because of the too great rigidity of the legal mind as now trained, the initiative, the referendum and the recall as remedies for the difficulty must be considered along with other possible remedies. If it be true that our system has broken down by reason of the inability of our courts to bear the burden placed on them, the 
next most feasible plan is that of "responsible government" under an unwritten constitution, as it exists in other countries, and to this the initiative, the referendum and recall, if applied in a wide sense, seem necessarily to lead.

It therefore becomes necessary to examine the philosophical and legal basis on which our system rests, and to make up our minds whether our system is reasonable and practicable and as good as or better than any other. If we conclude that it is, and that therefore the functions which we have given our courts are reasonable and capable of being properly performed by them under all ordinary circumstances, it will be necessary to attempt to discover the reason why some of them have happened to make the decisions which are regarded as retrogressive. If we succeed in discovering these reasons, it will particularly be necessary to consider how far the initiative, the referendum and the recall can be used, if they can be used at all, as a means of remedying any aberrations of our courts in performing their superintending and nullifying functions.

An attempt will first be made, therefore, to state the philosophical and legal basis on which our system rests. The simplest way seems to be to state the propositions of politics and law which underlie our system, beginning with the most fundamental and proceeding by successive steps to the various derivative propositions, illustrating each, so far as space will permit, by reference to historical facts.

The fundamental proposition upon which our system rests, as it would appear, is, that governments are the agents of the governed. There are, as history, experience, and philosophy show, in the last analysis, only three forms of government-the patriarchal form, the agency form, and the imperial form. In the patriarchal form governmental power is conceived of as derived from a source external to the people governed, that is, from God, and is devolved from above downward upon subordinate $o$ icers and subjects. In the agency form, governmental power is conceived of as derived from the people governed, who delegate limited powers to officers who are neither above nor below the people, but are on an equality with the people as contracting parties and agents. In the imperial form, all power is conceived of as derived from the people governed, who are assumed to have conveyed all their powers to a ruler or government, so that the ruler or government thus has a power equally absolute with 
that of a patriarch and devolves his or its power from above downwards upon subordinate officers and subjects.

When, therefore, it is said that our system depends upon our acceptance of the proposition that governments are the agents of the governed, it is the same as saying that we have chosen to adopt the agency system of government and have not allowed ourselves to be subjected to the patriarchal system or to the imperial system.

It becomes important, therefore, to inquire what is necessarily involved in the acceptance of this fundamental proposition-that is, to inquire what are the fundamental principles of agency. About this there is no di iculty. Agency is one of the most common and necessary of human relations. The fundamental principles of agency have been settled for at least fourteen centuries. These principles were summed up in the civil law by two maxims. The first of these was, Obligatio mandati consensu contrahentium consistit; a translation of which is, "The powers of an agent are derived from the consent (or agreement) of the contracting parties." The second was, Rei turpis nullum mandatum est; a translation of which is, "There can be no agency to do an unjust (or wrongful) act." The meaning of these two maxims is, that the agent has no powers except those delegated to him by the principal and accepted by the agent in the agreement of agency made between them, and that any acts done by the agent in excess of these powers are void as to the principal; that even if the agent acts within the powers thus delegated to and accepted by him and agreed to by both parties, yet if in so acting he does an unjust or wrongful act to any one,-as distinguished from an act of negligence,-the wrongful act is in excess of his powers, and is void as to the principal; and that even if the principal and the agent agree that the agent shall have power to do wrong or injustice, the agreement is void as a contract of agency and operates only to make the principal a wrong-doer jointly with the agent, in case the agent does the wrong or injustice. When we say, therefore, that our political system is based on the agency theory, we mean that our governments have no powers except those which are delegated to them by the people and accepted by the governments by acceptance of office, and which are agreed to between the peoples and the governments; that even if our governments act strictly within the letter of the powers granted, they have no power in exercising those powers to do injustice to any one; and that if the people 
should attempt to delegate to any of our governments a power to do injustice, the attempted delegation of power would be void, and the governments would have no power to do injustice.

The first great public document in which this theory was foreshadowed was Magna Charta. This great charter, granted by King John to the Barons in 1215, was made, however, under such circumstances and was couched in such language that it required interpretation. In subsequent confirmatory charters granted by the English kings to the people by act of parliament, these principles gradually became more clearly stated. The Reformation, by emphasizing the importance of the individual and his direct relationship to God, gave a wide extension to the idea that all institutions, including the institutions of government and church, are for the benefit of the individual; and it was a natural and necessary conclusion that all the persons concerned in the management of institutions and the institutions themselves were agents of those for whose benefit they existed. The people of Continental Europe, however, long accustomed to regard themselves as members of clans or armies, and to regard the head of their nation as invested with patriarchal or imperial power, were not able to apply this theory successfully against the opposition of those attached by conviction or interest to the patriarchal or imperial theory.

The principle that governments are the agents of the governed was recognized in the charter granted by the king in council to the Massachusetts Bay Colony in 1629. By that charter it was provided that the freemen of the colony should meet in general court every three months, and that at one of these courts, called the court of election, all the officers of the colony should be elected. In the Massachusetts Body of Liberties of 1641, this system was established by statutory provision, and it was also arranged that officials might be recalled for cause at any of the general courts other than the court of election by majority vote upon cause shown.

The same right of the citizens of the colonies to elect all their own officers was recognized in the Rhode Island charters of 1643 and 1663, and in the Connecticut charter of 1662. The colonies regarded these charters as the ones which really expressed the full extent of their political rights, though other colonial charters provided for appointment of the governor, and in some cases the governor and upper house, by the King of Great Britain in council. 
The Continental Congress was from the outset a congress of agents of the colonies. When that congress adopted the Declaration of Independence, it committed the United States for all time to the agency theory. It was declared that governments are instituted among men for the benefit of the individual and primarily to protect and preserve each individual in the reasonable exercise of those attributes of life, motion and prehension which are common to all human beings and which are essential to the existence of every human being. It was declared that each individual has a divine right, by reason of the fact that all are equally created by God with these attributes, to life, liberty (motion) and the pursuit of happiness (prehension). "To secure these (divine) rights" of the individual, the Declaration asserts, "governments are instituted among men," evidently meaning either by their consent or by external force. However governments may be instituted, whether by consent or force, the Declaration declares, they are the agents of the governed. The words are: "That to secure these rights, governments are instituted among men, deriving their just powers from the consent of the governed." This clearly means that governments have no power to do any unjust acts, and that all their powers to do just acts are derived from the agreement of agency between the government and the governed. The expression "deriving their just powers from the consent of the governed" seems clearly to be a combination of the two maxims of the law of agency above quoted, that the powers of an agent are derived from the consent (or agreement) of the contracting parties, and that there can be no agency to do an act which is unjust or wrongful to any one.

The second proposition on which, as it would appear, our system is based, and which is a derivative from the first, is, that states are corporations. If governments are the agents of the governed, the whole organization consisting of the government and the governed permanently operating together as one mechanism or body, is an artificial person or corporation. The people governed are in this view the members of the corporation, and the government the officers and board of directors of the corporation.

The principles of the law of corporations are those of the law of agency. The corporation, regarded as an artificial and legal person, is the agent of its members. Its powers are those which are agreed to between it and the members; the members delegate specific powers 
to the corporation, and the corporation accepts them. The corporation has no powers except those delegated by the members, and even if it acts within the letter of those powers it has no power to do an act which is unjust or wrongful to any one. Any act of a corporation in excess of its powers is void. Even if the incorporators or the state should attempt to give the corporation power to do injustice to any one, such attempted delegation would be void, and the corporation would have no power to do injustice.

Prior to the Reformation the conception of a number of persons united for a common purpose under a governing body of agents selected by them, as an artificial person which was itself the agent of the members of the corporation, though not unknown, was little understood or applied. Religious, charitable and educational corporations existed, but cities, towns and trade-guilds furnished the principal examples of political or industrial corporations. So far as there was anything corresponding to the modern territorial state, it was not conceived of as a corporation, but as a family or clan. The city-states and small republics of Europe, however, to some extent recognized themselves as corporations. The possibility of regarding territorial communities as corporations was also made manifest when the republics of Venice and Genoa, in the fourteenth and fifteenth centuries, chartered corporations for trading and banking purposes with powers of government over the colonies of merchants on the shores of the Black and Egean seas. This practice was soon followed by France, Iolland and England. It only needed that the colony should grow strong enough to control the corporation for the colony to consider itself as the corporation and to elect its own officers. The idea of a "commonwealth," or a corporation on a fixed territory having for its purpose the common weal of the persons there residing and inhabiting, was the logical result of the social, economic, political and religious ideas and theories which the Reformation brought forth. Granting that the development of the individual is the important thing to be considered both in theology and politics, and that all institutions are for this purpose, it follows that it is not only the right but the duty of each individual to assist in molding the institutions which are for his benefit. By conceiving of a group of persons united for a common purpose as a personality outside of and distinct from them all, and as the agent of all, the institution was brought under the control of the group, the artificial personality being the agent of the group. 
At the time the colonization of New England began in 1621, the corporation theory of the state was just beginning to take strong root in England. This theory was opposed by the ruling classes as a whole, though some of the nobility and a great part of the well-to-do farmers and professional men believed in it. Those who emigrated from England to America at this time did so because they believed that governments are and of right ought to be the agents of the governed, and that states are and of right ought to be corporations. In the "Mayflower Compact" of 1621, entered into between the members of the colony which afterwards settled in Plymouth, Massachusetts, the colonists "covenanted and combined" themselves into "a civil body politic" for their "better ordering and preservation." The charter of the Massachusetts Bay Colony of 1629 provided that the persons named and their associates should be a "body corporate and politic." The people of Connecticut by their "Fundamental Orders" in 1638 "associated and conjoined" themselves as a "public state and commonwealth." In 1641, the Commissioners to Regulate the Colonies appointed by the Lords and Commons after Charles I had refused to act with them on account of their insistence on the agency theory of government, granted to Roger Williams and his associates at Providence Plantations "a free charter of civil incorporation and government" by which the colony was given the name of "The Incorporation of Providence Plantations." The charter of Connecticut of 1662 declared that the persons named and their associates should constitute "one body incorporate and politic," and the same language was used in the Rhode Island charter of 1663. In all these charters provision was made for election of all the officials by the members of the corporation, and these colonies were treated by the English government as English corporations. This, however, the colonies contested. They claimed that they were American corporations, and states, created by the voluntary act of the members, and that the charters granted by the English government were mere authentications or approvals of the voluntary union of the colonists. In this they were in accord with the trend of modern thought. More and more it is beginning to be realized that corporations are created by the act of the members and not by the act of the state, and that when the state "grants" a charter of incorporation its act is in legal effect merely an act of authentication and approval for reasons of convenience, and not in a true and real sense of grant 
of corporate powers. It is on account of the realization of this fact that progressive states now-a-days allow corporations to organize themselves under general laws.

After the colonies became independent, the idea that they were at once states and corporations was universally accepted and acted upon.

The third proposition on which the American system, as it would appear, is based is, that corporations may be formed of corporations. This proposition is now a familiar one to us in the industrial and social as well as in the political world. As a corporation is a legal person, there is no reason why it cannot be a member of a corporation. The idea that a corporation may with other corporations, or even with other natural persons, form a corporation, is now so familiar to us as to be a commonplace. The modern "trusts" for industrial purposes and the modern "federations" of trades unions or other corporations for social purposes, are made up of corporations as members. A holding or "trustee" or "federating" corporation is created by the combining corporations which is given federal powers for the common purposes. The whole organization constitutes a corporation composed of corporations.

The conception of a corporation composed of corporations which should also be a state, was first worked out or at least foreshadowed by an arrangement between the colonies of Massachusetts Bay, Plymouth, Connecticut and New Haven, made in 1643, when England was paralyzed by civil war and the colonies, surrounded by enemies, were thrown on their own resources. These four colonies entered into a "Consociation" or "Confederation," declaring that they did so "for mutual help in our common concerns, that as in nation and religion so in other respects we be and continue one." The new federal corporation, by the name of "The United Colonies of New England," was governed by a board of eight commissioners, two from each colony; the board having power, by a three-fourths vote, to bind the whole federal corporation and state for certain specified purposes. This corporation composed of corporations continued in existence and operation for over thirty years, dealing with the common interstate concerns of these four colonies and with their foreign interests, without much interference from England.

From 1690 forward various schemes were proposed for federating the American colonies so as to form one federal corporation or state 
either under Great Britain or in federation with that state. Among others, William Penn in 1697 formulated a very definite and complete plan. None of the plans for this purpose, however, was acceptable, but an arrangement was devised which, as it evolved, resulted in uniting the colonies and Great Britain into one corporation or state, which the colonies regarded as a corporation composed of corporations, to which the name "the British Empire" became attached. From 1696 until 1765, there existed in England a governing tribunal for the common purposes of Great Britain and the colonies which was made up of members of the King's Privy Council. This tribunal was called "the Committee of the Privy Council for Plantation Affairs" and was assisted by a subordinate body called "the Commissioners for Trade and Plantations." The whole British Empire, composed of Great Britain and the colonies was, as matter of fact, in cases arising before the tribunal, treated as if it were a corporation composed of corporations and as if it were a federal state composed of states; the state of Great Britain being in fact treated as the ruling state for the common purposes.

The fourth proposition on which the American system is based, it would seem, is, that to the convenient and orderly existence and operation of corporations, and of states which recognize themselves as corporations, written charters or constitutions are necessary. This is because limitations of power can be made effective only as they are carefully formulated in writing and published so as to be known to all concerned. As corporations are by their definition artificial persons and agents with limited powers, and as their officers are agents oftentimes linked together in a complex series of operations where there is a great division of labor, it is essential to their orderly and convenient management that these limitations of power should be formulated in written constitutions. The more complicated the corporation the more necessary the written formulation of the limitation of powers. Hence a written constitution is even more necessary to a federal state, which is composed of states, than to a compact state

The discussion that was carried on prior to the American Revolution concerning the limitations of the powers of Great Britain and the colonies as constituent elements of the great state and corporation called "the British Empire," called attention to the necessity of written constitutions. It had long been recognized that corporations 
for industrial or social purposes could not conveniently exist except under written charters. Cities and towns also had discovered the necessity of having written charters. All the American colonies except Virginia and New York were organized under charters recognizing more or less completely their corporate character, and the colonies had thus learned to appreciate the convenience of having their fundamental law contained in one document. The study of the relations between Great Britain and the colonies brought out the fact that the complex corporate and political unity called "the British Empire" was under a constitution of its own quite different from that of Great Britain. It also brought out the fact that there was a great difference of opinion as to what the provisions of the constitution of the British Empire were or ought to be. All Americans agreed that the empire was an aggregation of states under the headship of Great Britain, and that the powers of each of the constituent states were limited in such a manner that the whole British Empire could hold together and operate for the common good. It was pointed out by writers on both sides of the water that so large and complex an organization of states ought to exist under a plan of organization carefully formulated and written down in one document, so as exactly to express the limitations of the various agencies composing the government. The first act of the Continental Congress after deciding upon a declaration of independence, was to set about making a written constitution for the union of the colonies as states and corporations. All the colonies except Connecticut and Rhode Island, in accordance with the suggestion of the Continental Congress, adopted new written constitutions. Connecticut and Rhode Island, having power under their colonial charters to elect all their own officers, adopted their colonial charters as their state constitutions, and lived under them for many years after they became states.

The fifth proposition on which the American system is based is, as it would seem, that in order to keep the various agencies in a corporation working within their proper spheres and in harmony with each other, there must be somewhere in the organization a superintending agency with power to nullify the action of all other agencies which is in excess of the powers which these agents ought properly to exercise. Where a corporation is composed of corporations and the constituent corporations are thus at the same time agencies of government and members of the larger corporation, the necessity 
of having some superintending and nullifying power to secure the proper working of the complicated mechanism becomes still more evident.

In the prevailing thought of the Americans, the king in council was the agency in the British Empire in which this superintending and nullifying power was lodged. The majority of the Americans regarded the Lords and Commons of Great Britain as the local legislature of Great Britain, and insisted that it was the duty of the king advised by his privy council, as an arbitral and judicial tribunal, to use his veto power as a nullifying power for the purpose of nullifying even acts of parliament which this tribunal should find to be in excess of the powers which Great Britain ought properly to have exercised as a constituent state and a governmental agent of the British Empire. It was because they considered that George III had failed and refused to exercise this superintending and nullifying power, as the superintending and nullifying agency of the whole empire, and had united with his ministers and the lords and commons in attempting to assume patriarchal or imperial power in the federal state called "the British Empire," that he was held responsible in the Declaration of Independence for the disintegration of this federal state.

The sixth proposition on which, as it would appear, the American system is based, is, that the superintending and nullifying power is an agency of a judicial, and not of a legislative or executive nature; and that therefore, although it is an extraordinary kind of judicial power, it may more safely be committed to the judiciary than to the executive or the legislative or to an extraordinary agency outside of the legislative, the executive and the judiciary. Such an extraordinary agency might easily pervert a superintending and nullifying agency so that it would become in fact a patriarchal or imperial power.

In the first written federal constitutions adopted by the American Union, it was sought to avoid the necessity of a superintending and nullifying tribunal by establishing between the colonies merely a permanent alliance or confederation advised by a Congress of ambassadors. The Declaration of Independence was itself in part a written constitution of union of the American states, for in it they described themselves as "The United States of America;" but as it contained no specification of the powers which the union, as distinct 
from the states, should exercise, it created only a permanent alliance or confederation. The articles of confederation specified the powers of the union; the powers granted to congress being those which before the Revolution the king in council had exercised over the colonies as the federal head of "the British Empire" with their consent. These articles made no provision for any superintending and nullifying agency. They, however, denied to the union any power to lay or collect taxes, or to regulate interstate or foreign commerce, or to acquire or govern colonies. As these were the powers respecting the exercise of which in the empire Great Britain had made excessive claims of power, and out of which the dispute between Great Britain and the colonies had arisen, it seems to have been hoped that, by withdrawing these powers altogether from congress, disputes regarding the limits of powers would be avoided, and thus no superintendence or nullification would be required.

The Constitution of the United States, adopted in 1787 , conferred these three disputed powers on the union and provided a method for nullifying acts done in excess of power by the union or by the states. This nullifying power as respects the limitations placed upon governments and states by that constitution, was vested in the Supreme Court of the United States in the last instance, though permitted to be exercised by all the courts subject to the final decision of the supreme court. It was thus recognized as a judicial power, though of an extraordinary kind. This was logical; for the question whether an agent, a governmental officer, a corporation or a state has exceeded his or its powers, can best be decided by the hearing and examination of evidence and the application of legal principles.

The seventh proposition on which the American system, as it would seem, is based, is, that in order to enable the judiciary to exercise its superintending and nullifying agency to prevent excess of powers of the other agencies of government, it is necessary that the constitution of the federal state should be made the supreme law of the federal state, and that the constitution of each state should, subject to this supreme law, be the supreme law of the state. By such an arrangement, this extraordinary power of the courts is exercised as a part of their ordinary judicial functions in hearing and adjudicating cases between ordinary parties litigant, and there is little possibility that power exercised in this non-spectacular manner will ever be given 
any spectacular setting so as to lead to the popular belief that the depositaries of this power are really exercising a patriarchal or an imperial power. The citizen, observing the courts laboriously investigating facts and basing their decisions upon subtle distinctions of law drawn from experience and reason, is not likely to regard the courts as patriarchs or emperors. The safety and permanence of the whole agency system of government in states may, indeed, be said to depend upon the acceptance by the people of the proposition that the limitations of the powers of their governmental agencies are under a supreme law established by the people and interpreted like other law by the courts. Only through the prevalence and acceptance of this idea can there be assurance at all times against the recrudescence of patriarchal or imperial power.

The courts in the United States were, by the constitution of 1787, given jurisdiction to superintend and nullify all action of any of the governments limited by the Constitution of the United States by means of a provision which made the constitution, and the acts of congress in conformity with the constitution, "the supreme law of the land." Under this provision the constitution is applied by the courts, with final appeal to the supreme court, in the same manner as other law, except that it is treated as supreme so that any governmental action inconsistent with its provisions is void. In the same manner, the constitution of each state is its supreme law, subject to the Constitution of the United States which as to the limitations upon governmental power contained in it is supreme over all law throughout the United States.

Enough has been said, it is hoped, to have satisfied the reader that our form of government is based on the propositions that governments are the agents of the governed; that states are corporations; that federal states are corporations composed of corporations; that in all corporations written constitutions are necessary to determine the limitations of the powers of the officers of the corporation and of the corporation itself; that in the case of corporations composed of corporations, written constitutions are still more necessary to fix the limits of the complex agencies; that within every corporation, and especially within every corporation composed of corporations, there must somewhere be vested a superintending and nullifying power and agency, which can promptly and effectively nullify all action done in excess of power, so as to keep the whole mechanism 
and the whole artificial personality working to its full capacity and effectiveness; that it is safer, as preventing the possibility of the recrudescence of patriarchal or imperial power, to vest this superintending and nullifying power in the judiciary rather than in the legislative or the executive, or in any extraordinary governmental agency outside of and distinct from the legislative, the executive and the judiciary; and also more logical, since the superintending and nullifying power is judicial in its nature; and that it is necessary, in order that the judiciary should exercise this great power, that our written federal constitution should be the supreme law for federal purposes and our state constitutions supreme law for state purposes.

Our system is therefore just, scientific and practical. It is more just, more scientific and more practical than any other system; for none would now assert that the patriarchal or the imperial theory of government is more just, more scientific and more practical than the agency theory, and all other systems are based on compromises between the agency theory and the patriarchal or imperial theory.

It therefore re sains to attempt to discover in what respect our system is at the present time operating badly, and to attempt to suggest a remedy; and particularly to inquire whether the remedy can be had by the use of the initiative, the referendum or the recall.

A constitution of a corporation or of a state must evidently deal with four different subjects:

First. The organic structure of the corporation or state-that is, the relations which the parts of the mechanism bear to each other.

Second. The relations between the governing board of the corporation or the government of the state, and the individuals composing the corporation or state as members of the corporation or citizens.

Third. The relations between the corporation or state and its members or citizens, and those corporations or states with which it is federally or permanently connected or united, and their members or citizens.

Fourth. The relations between the corporation or state and its members or citizens, and those corporations or states with which it is not federally or permanently connected or united, and which are "foreign" to it, and their members or citizens.

The present defects in the working of our system are not with respect to the relations described in the first, third or fourth specifica- 
tion. There is no complaint of the rulings of our courts in constitutional cases involving the relations between the different parts of our state and federal governments or between the Union and the states as parts of the mechanism of the Union, or involving our relations with our protectorates or dependencies, or with foreign nations, or with the citizens of any of these countries, or between our citizens and any of these countries or their citizens. The present complaint arises exclusively under the second specification. It is charged that our courts have ruled erroneously in constitutional cases involving the relations between the state and its citizens and inhabitants. In nearly all the cases where the courts are alleged to have made these erroneous constitutional decisions, their decisions have been zade under constitutional provisions which declare that "no person shall be deprived of his life, liberty or property without due process of law."

On examining the decisions, it will be found that this constitutional provision has been gradually growing in importance in the estimation of the courts, until now it is regarded as furnishing a general test of the constitutionality of governmental action. In so interpreting this provision, it seems that the courts have erred.

By referring to the Petition of Right of 1627 , presented by the lords and commons of England to Charles I, where the expression "due process of law" first occurs in a constitutional document, we shall find that these words are there used exclusively as applied to cases where a man's life, liberty or property is taken away on account of his alleged wrong-doing. The expression occurs in that petition only in the following statement:

"That no man, of what estate or condition that he be, should be put out of his lands or tenements, nor taken nor imprisoned nor put to death, without having been brought to answer by due process of law."

As respects the receipt by the government of the property of good citizens as taxes to be used for the public benefit, the Petition of Right does not use the expression "due process of law," but the word "consent." That provision reads:

"That [the people of England] should have this freedom, that they should not be compelled to contribute to any tax, tallage, aid or other like charge not set by common consent in parliament."

Lord Coke, who is often wrongly quoted as authority for using the "due process of law" provision as a test of the validity of all 
forms of governmental action, held that quite a different test ought to be applied. In Bonham's Case ( 8 Coke, 115-118a), decided in the court of common pleas in 1611, while Coke was chief justice, he said, delivering the opinion of the court:

"When an act of parliament is against common right and reason, or repugnant, or impossible to be performed, the common law will control it and adjudge such act to be void."

His successor in the chief justiceship, Hobart, in the case of Day $v$. Savadge (Hobart, 87), decided about 1620, said, in delivering the opinion of the court:

"An act of parliament, made against natural equity, as to make a man judge in his own case, is void in itself; for jura naturae sunt immutabilia, and they are leges legum (for the laws of nature are immutable, and they are the laws of laws)."

As late as 1701, Holt, Chief Justice of the Court of King's Bench, in the case of City of London v. Wood (12 Modern, 669), approved Lord Coke's statement in Bonham's case.

The American lawyers from the period of the Stamp act onward, led by James Otis, adopted the view of Coke.

John Adams, in his autobiography, gives an account of the drafting of the first resolutions of the Continental Congress by the committee of which he was a member. One question, he tells us, was whether the resolutions should declare the powers of Great Britain over the colonies to be limited by "the British constitution and our American charters," or whether they should "recur to the law of nature" as the basis of their claim to have rights as the governed, against Great Britain as their supreme, but legally limited, government. He says that he was "very strenuous for retaining and insisting on" the law of nature. The resolutions as adopted declared that the limitations of the governmental power of Great Britain as respects the colonies and their inhabitants existed "by the immutable laws of nature, the principles of the English constitution, and the several charters or contracts." It was natural, therefore, that in the Declaration of Independence our ancestors should have based their claim to be absolved from their former political connection with Great Britain, and to be independent states, on "the laws of nature and of nature's God;" and that they should have asserted that governments, however instituted, can only exercise such powers as are just, as agents of the governed. Not to have 
inserted this limitation that the powers exercised by government must be "just" would have been to have rendered the Declaration inconsistent with their previous contention, and would have made the framers justly chargeable with bad faith. Having insisted in the controversy with Great Britain upon the universal principle that the powers of all governments are limited to those which are expressly delegated and which are just, it was logically obligatory upon them to adhere to this general principle in the Declaration of Independence and to make this principle applicable to every government and state which should ever be formed by the American people. That they intended to do so, and that they used apt words to do so, there can be no doubt.

The true limitations upon the powers of government in its relations with the governed, when its action is directed to the general welfare as a trustee for all, and not to the punishment or correction of an individual or a class of individuals as a guardian for the weak and deficient, are, it would seem, to be found in the preamble of the Declaration of Independence and in the preamble of the constitution. The Declaration is a federal constitution, since by it was formed the first union of the states. It is at the present time, in so far as it states general principles, our fundamental federal constitution. It has never been rescinded, nor in any way amended. It is not inconsistent with the constitution of 1787 . The constitution of 1787 recognizes the permanence of the principles set forth in the Declaration of Independence, and of those set forth in the Articles of Confederation except so far as they are inconsistent with the constitution, by declaring that its purpose is "to form a more perfect union."

The preamble of the Declaration of Independence asserts that "to secure these [unalienable] rights [of life, liberty and the pursuit of happiness], governments are instituted among men, deriving their just powers from the consent of the governed." This makes the test of the constitutionality and validity of all governmental action in civilized society, first, whether the action of the government was taken under powers derived from the consent of the governed,- that is, under the delegation of powers contained in the agreement between the government and the governed; and, second, if the action was so taken, whether it is just as complying with the natural laws of the material universe and with those principles which in civilized society 
are universally recognized as fundamental; which are formulated, perhaps as well as anywhere, in the Ten Commandments of the Old Testament and in the Two Commandments of the New Testament. This same limitation upon all governmental action is implied in the preamble of the Constitution of the United States when it declares that the people of the United States have ordained and established the constitution in order "to establish justice." Even in states where there is no written constitution specifying the particular powers delegated to the government, there exists from the necessity of the case a general limitation upon the powers of government, so that the courts can nullify all governmental action which is unjust.

That there must be a general power in any superintending and nullifying agency within a corporation to nullify any action of other agencies which is palpably absurd or unjust, goes without saying. A state or national law which should enact that a horse should be a man, or that two and two should make five, or which should give a reward to persons convicted of theft or murder, would of course be held void by any court of any state or nation in the world, as violating the natural laws of the material universe or the fundamental principles of social justice as laid down in the Decalogue. Our courts can find ample authority for nullifying such acts in the provision of the Declaration of Independence which declares that governments can exercise only "just" powers and in the provision of the preamble of the constitution that one of the purposes of the union is "to establish justice."

In the early constitutions of the states and in the fifth amendment of the Constitution of the United States, the expression "without due process of law" was used in the same connection as in the Petition of Right - that is, as limiting the power of the government to take away the life, liberty or property of the individual only when the governmental action is directed against an individual for alleged wrong-doing. In this connection the words meant that a person charged in court by another person with wrong-doing, or threatened by governmental action with loss of life or liberty or confiscation of property for alleged wrong committed against the state, could not be held by the government to be civilly liable and could not be penalized criminally except according to a proper procedure established in advance by law and according to principles of law duly formulated. In the fourteenth amendment, however, which was adopted after 
the Civil War, for the purpose of giving the federal government power to prevent the southern states from reinstituting slavery by indirect means, the provision that no state shall "deprive any person of life, liberty or property without due process of law" was inserted in a connection where it might equally well be understood as covering cases where the state receives the property of honest citizens by way of taxation, or makes general regulations for the public good, and where it is seeking to take away life, liberty or property from persons who are charged with wrong-doing. The courts, under the leadership of the Supreme Court of the United States, have construed this provision as applying to all kinds of governmental action. In so holding it seems that the courts have clearly erred; since the expression "without due process of law," as applied to all kinds of governmental action other than that whereby the government seeks to take away the life, liberty or property of the individual on the ground that he is a wrong-doer, is clearly meaningless.

As the natural result of the attempt by the courts to use the words "without due process of law" as the general test of the validity of all governmental action when these words have no meaning except as applied to one kind of governmental action, our decisions in constitutional cases involving the relations between the government and the individual have become illogical and confused. The attempt to draw a meaning out of an expression which is meaningless because used in a wrong connection must necessarily lead to confusion. As the courts have applied an obscure and unreasonable test in the greater part of the cases involving the relations between the government and the governed, they have naturally fallen into the way of deciding these cases according to the personal or partisan notions of the judges.

The true test, when laws passed in the exercise of the taxing power or the police power are claimed to be unconstitutional on general grounds, is, it would seem, not whether they comply or not with the "due process of law" provision, but whether or not they are "just." In applying this test, the courts will of course not hold an act of the legislature not to be "just," unless it is so clearly "against common right or reason, or repugnant, or impossible to be performed," or "against natural equity" that for the court to uphold it would be to make the court an instrument of injustice instead of a court of justice. Thus in cases of policy, where no 
moral right or wrong was involved, the legislature would finally determine the rate of social and economic progress; the courts following the legislature.

In the present situation, therefore, when our judiciary is under criticism, it seems that if the fourteenth amendment is agreed to be so worded that it requires the courts, in all cases involving the relations between the government and the governed, to decide by the test that the state shall not deprive the individual of his life, liberty or property without due process of law, that amendment ought to be amended. It would be sufficient if the words "for alleged wrongdoing" were inserted before the words "of life," so that the phrase would read "nor shall any state deprive any person, on account of alleged wrong-doing, of life, liberty or property, without due process of law." In case of governmental acíion aimed at individuals or corporations on account of alleged wrong-doing, it would then be the duty of the courts to see that the alleged wrong-doer had a fair hearing and trial under an appropriate process established by law, and according to principles of law duly established.

But perhaps no such amendment is necessary. It may be considered that the fourteenth amendment was not intended to have the broad signification which the courts have attached to it, and that the natural meaning to be given to the words above quotedespecially as the words "deprived of his life, liberty or property" are used, which almost necessarily mean a taking away on account of wrong-doing-is the restricted one according to which the provision in which these words occur is confined to governmental action directed against alleged wrong-doers. If so, the words are ambiguous, and the courts can by their own construction give the amendment its proper meaning.

The provision denying to governments the power to deprive individuals of their life, liberty or property without due process of law is one which occurs in most of the state constitutions, and the state courts have followed the United States Supreme Court in construing it as applying to all forms of governmental action by state governments. If by constitutional amendment or by construction of the United States Supreme Court the restricted meaning above mentioned is given to this provision, the effect would be to induce the state supreme courts to restrict the meaning of these words in the state constitutions, and the confusion which has been caused by 
attaching too wide and general a meaning to this constitutional provision should, it would seem, tend to cease.

If the courts should thus by a proper construction of the words "due process of law" be put in the position where they would have to apply specific and easily understood limitations of governmental powers as tests in exercising their superintending and nullifying power, with the addition that they were obliged to nullify any governmental action that was clearly not "just," it is probable that there would not be much dissatisfaction with their constitutional decisions. If the issue was as to the application of a specific and plainly worded constitutional limitation, there would not be room for much personal or partisan reasoning by the judges. If the issue were as to whether a particular governmental action was "just," the court would hold such action unconstitutional only in case it was clearly absurd or impossible, as being opposed to the natural laws of the material universe, or in case it was clearly wrongful as being opposed to the fundamental principles of social justice formulated in the Ten Commandments of the Old Testament and in the Two Commandments of the New Testament. The natural laws of the material universe are necessarily fundamental law; and it is not too much to say that the Great Commandments are now accepted, in theory at least, throughout the society of nations, as fundamental law. Courts in determining whether governmental action was or was not just would in fact be sitting not as state or national courts, but as courts of the society of nations; for the same principles which would determine whether a certain governmental action was unjust in one nation, would equally control in a similar case in every other nation, and any court in deciding such a case would in a very true sense be applying the constitutional law of the society of nations as the supreme law.

In passing it may be said that this conception of our national courts sitting as courts of the society of nations is not a fanciful suggestion, but is a practical political fact. More and more statesmen and publicists everywhere are realizing and accepting as a fact of practical politics that there is a society of the peoples, states and nations of the world, which for want of a better name we call "the society of nations;" that this society is a corporation composed of corporations and a federal state, having a federal government which is the agent for the common purposes of the peoples, states and 
nations governed; that this federal government does not consist of a body of definite persons, collected together in one place as the capital, and is not elected on the representative basis, but is made up of nations, states, governmental officers of nations and states, and publicists, scattered over the face of the earth, and is carefully arranged so as to protect the rights of the weaker states and nations and of all minorities; that this inclusive society and federal state has by various legislative methods formulated and is still formulating its own federal constitutional, statutory and customary law, commonly known as "international law;" and that it is daily enforcing its federal law by various executive methods and particularly through the nations and states as its executive organs; and that therefore national courts, in determining what is "just," are not at liberty to consider alone what is regarded as just by the "common juridical conscience" of their own nation, but must also consider what is regarded as just, and treated as fundamental law, by the "common juridical conscience" of the society of nations.

We may, therefore, it would seem, reasonably hope that by making all our special constitutional limitations clear and distinct and easily understood,--which we shall do by giving the "due process of law" provisions a restricted meaning so that they will apply only where governmental action is directed against individuals as alleged wrong-doers,- and by making the only general test of constitutionality the test of "justice,"-regarding "justice" as that which is considered just by the "common juridical conscience" of the society of nations, - the courts will, as a general rule, act in a manner satisfactory to the enlightened intellect and conscience of the people. But when all precautions are taken it may still happen that the courts, as the superintending and nullifying agencies of our states as corporations, will occasionally err and will themselves exceed their powers and act unconstitutionally. The question arises, what shall be the remedy in such a case.

One remedy which has already been frequently applied, is to amend our constitutions so as to recall the erroneous decisions and validate future governmental action of the kind which the courts have wrongly nullified. But such a process of amending our constitutions is dangerous to our system. Our written constitutions by such amendments are ceasing to be statements of fundamental principles and are becoming confused legislative codes. Thus by 
this method of attempting to remedy the difficulty our written constitutions are being indirectly destroyed. It is necessary, therefore, to consider other possible remedies.

If we agree that states are corporations, the remedy to be applied where the courts of a state exceed their powers to superintend and nullify other agencies and nullify wrongly, is the same as would be applied in a corporation if a superintending and nullifying official in a corporation should wrongly exercise his powers of superintendence and should nullify action which he ought to have allowed to stand as valid. The members of the corporation, while indulging in every presumption in favor of the superintending and nullifying official, and relying, as reasonable men ought to do, upon his expert judgment to the fullest extent possible, would, if they were satisfied beyond a reasonable doubt that he had nullified action of an agent which he ought not to have nullified, either remove him by vote of the majority of the members or validate by similar vote the action which he purported to nullify.

This seems to be what is meant by "the recall of judges" and "the recall of decisions," as these expressions are now used by those who believe our courts have erred. The recall of judges is, however, used in two senses which it is necessary to distinguish from each other. There is a recall of judges for incompetence, and a recall of judges for having participated in constitutional decisions by which governmental action has been wrongly nullified. The recall of judges for incompetence, and the recall of judges for participation in constitutional decisions which are erroneous, stand on entirely different grounds. Every state or nation ought to have some orderly method of removing judges for incompetence. Impeachment does not meet such a case, since impeachment is permissible only where moral turpitude can be proved. The best method of removal see is to be by action of the legislature addressed to the executive, though there appears to be no serious objection to a referendum for this purpose if the people prefer it, and it happens to work well in a given state or nation. The recall of judges for participation in constitutional decisions in which governmental action is erroneously nullified, or the recall of these decisions, must be by referendum, if at all; though the referendum need not actually remove the judges or actually reverse the decision. That the people assembled may exercise this right without necessarily destroying our system is evident. That, 
in extreme and clear cases, they not only may but ought to exercise in some manner the right to validate governmental action wrongly nullified by the courts is also evident. That this is a dangerous power to be exercised by popular vote is also evident, since it is only in extreme and rare cases that the popular judgment would be likely to be more correct than the expert judgment of the courts. If exercised frequently and if exercised wrongly, it would tend to unsettle our whole system and in the end would probably destroy it. But that a power is dangerous to exercise, is no reason why it should never be exercised. That it is dangerous is a reason for using caution when the power is exercised, and the more dangerous it is the greater ought to be the caution in exercising it.

The recall of judges and the recall of decisions, when used to correct aberrations in the constitutional action of the courts, should undoubtedly be used rarely, and only in extreme cases and as a last resort; and even then with caution and under the most careful safeguards. It should always be remembered that the decision of a court is final only in the case decided, and is never final as settling legal principles; that it is generally the part of wisdom to trust to experts in matters which are complicated and which can be fully mastered only by experts who give their lives to learning the art; that the court as an institution is everlasting; and that though one bench of judges may err, another bench may correct the error, so that the court as an institution is never likely to be wrong except temporarily. Considering the dangers of the recall of judges or the recall of decisions, it seems that it is on the whole safer, in all but the most extreme and rare cases, to trust to the courts correcting their own errors by the pressure of public opinion; never allowing them to forget, however, that they are only the superintending and nullifying agencies of the state as a corporation, and that the people of the state as members of the corporation have the right, which they can and will exercise in the last resort, to annul unconstitutional action of the courts as such superintending and nullifying agencies and to validate the nullifying action, or, at their option, to remove the judges who have thus erred. To grant that the courts in the United States have powers not subject to control by the people in the last resort is to make the courts the American patriarchs or emperors. Like every other governmental agency, our courts, whatever may be the functions they exercise, are the agents of the governed and form a part of 
the managing boards of the states and of the nation as corporations. Though they have greater functions than the courts of foreign countries, they have a responsibility to the people which prevents the abuse of these great functions. There appears no likelihood that there will ever be such a use of the initiative, the referendum or the recall as will interfere with the performance by our courts of these functions; and there is much in the movement for recall of judges and recall of decisions to encourage the belief that sturdy manhood still persists throughout the American jurisdiction, demanding that governments shall be and remain the agents of the governed. 